\title{
CURRENT DISTRIBUTION AND HABITAT PREFERENCES OF RED DEER AND EURASIAN ELK IN THE CZECH REPUBLIC
}

\author{
DUŠAN ROMPORTL ${ }^{1,2, *}$, ANNA BLÁHOVÁ ${ }^{1}$, MICHAL ANDREAS $^{1}$, \\ EVA CHUMANOVÁ ${ }^{1}$, MILOŠ ANDĚRA ${ }^{3}$, and JAROSLAV ČERVENÝ ${ }^{4,5}$
}

\author{
1 The Silva Tarouca Research Institute for Landscape and Ornamental Gardening, Květnové náměstí 391, 252 43, Průhonice, \\ Czech Republic \\ 2 Department of Physical Geography and Geoecology, Faculty of Science, Charles University, Albertov 6, 12843 Praha 2, \\ Czech Republic \\ ${ }^{3}$ Department of Zoology of the National Museum - Natural History Museum, Václavské náměstí 68, 11579 Prague 1, Czech Republic \\ ${ }^{4}$ Department of Forest Protection and Game Management, Czech University of Life Sciences Prague, Kamýcká 129, 16521 Prague 6 - \\ Suchdol, Czech Republic \\ ${ }^{5}$ Institute of Vertebrate Biology Academy of Sciences of the Czech Republic, Květná 8, 60365 Brno, Czech Republic \\ * Corresponding author: dusan.romportl@natur.cuni.cz
}

\section{ABSTRACT}

Here we determine the distribution, numbers and habitat preferences of two of the largest species in the family Cervidae present in the Czech Republic, red deer and Eurasian elk. Red deer occurs predominantly in vast areas of forest, i.e. mainly in the mountains bordering this country and several large forest units in the interior. The range of this species has been increasing along with the size of its population. Areas of its permanent occurrence may be generally characterized as regions largely covered with deciduous and coniferous forests and pastures, and regions with a more diverse landscape. Red deer does not occur in areas that are mainly arable or urban, or in areas covered with extensive water bodies and wetlands. As these animals prefer large forests, they occur mainly at high altitudes where the terrain is rugged. The Eurasian elk permanently occurs in the Czech Republic in a single area located between the state border and the right bank of the Lipno Dam. Its home range has been diminishing, presumably along with its numbers. The area of its permanent occurrence is characterized by an abundance of coniferous trees, some pastures and water bodies. The Eurasian elk does not occur in areas covered with arable and urban land but also surprisingly in areas with mainly deciduous forest. Both species prefer high altitudes, but Eurasian elk prefers areas with little difference in the terrain vertically.

Keywords: habitat preferences, red deer, Eurasian elk

\section{Introduction}

Monitoring the home ranges of various species and their potential changes, induced by natural population, environmental factors, or by man, is one of the essential conditions for understanding their ecology, habitat requirements, or the threats to their survival. The present study addresses current knowledge on the distribution and habitat requirements of two of the largest species of deer in this country. Its main objective is to summarize and refine the existing data on the occurrence of red deer and Eurasian elk in the Czech Republic and to describe the connections between the current state of the landscape and the actual occurrence of the focal species. These two species were selected as representatives of large mammals with relatively high requirements for space, vegetation cover and a quiet environment.

\section{Material and Methods}

\section{Red Deer (Cervus elaphus)}

Red deer are currently patchily distributed throughout most of Eurasia. It reaches Ireland and extends over Central Asia, the Himalayas and China to Primorsky Krai and Korea. It also occurs in the northwest of Africa and North America (Anděra and Horáček 2005; Grubb 2005). In Central Europe, it can be found at various altitudes ranging from the lowest to approximately 2,500 m a.s.l. in the Alps (Koubek and Zima 1999).

In the past, red deer supposedly occupied most of our forests. Its populations became fragmented due to the extensive deforestation that has occurred mainly in the interior of the country (Anděra and Červený 2009).

The current distribution of red deer is closely associated with large forest complexes in the mountains and highlands, and its populations are subject to game management practices. In the Czech Republic, it continuously occupies border mountain areas and their adjacent foothills. These mountain ranges actually form a ring running from the Moravian part of the Carpathians, over the Sudetes in the north, to the Krušné hory Mts., further to the Šumava and reaching the Novohradské hory Mts. Inside the country, this species occurs at Brdy, Krrivoklátsko and in the Českomoravská vrchovina and Drahanská vrchovina uplands. Because of deforestation, it is rarely seen in the lowlands, with the exception of floodplain forests such as Soutok near Lanžhot (Anděra and Hanzal 1995; Hlaváč and Anděl 2001; Anděra and Červený 2009).

At present, red deer predominantly occurs in areas with continuous forest cover (coniferous, mixed and 
deciduous), but with numerous clear-cuts and pastures. They prefer clearings that have a rich layer of herbaceous plants (Welch et al. 1990; Anděra and Červený 2009). Where the Eurasian lynx is likely to occur, the red deer will seek open young growth providing both sufficient food and a safe hiding place (Čejka 2001). In autumn, animals leave their summer resting places at high altitudes and move to lower areas where they spend winter. Along with the melting snow in spring, they return back to the mountain areas (Mysterud 1999; Šustr 2007).

\section{Eurasian Elk (Alces alces)}

The distribution of the Eurasian elk extends from Norway across Sweden into Finland, Russia, Baltic countries, Belarus, Poland, and Ukraine to Siberia, reaching as far as the Yenisei River. However, this species is extinct in Western and a large part of Central Europe (Corbet 1978; Bauer and Nygrén 1999; Grubb 2005).

The Eurasian elk has never been abundant in the Czech Republic. The last records before its local extinction date back to the 16th century (Anderra and Kokeš 1978). Remnants of these animals can be found dating from the Early Middle Ages (approx. until the year 1200) at archaeological sites in the lowlands along the Labe and Ohře rivers, and in southern Moravia; there are no archaeological findings dated to a later period (Peške 1995; Kyselý 2005). Thus, it may be presumed that elks were rare in this country after the High Middle Ages. Nevertheless, migrating individuals were recorded in 1957 (Anděra and Kokeš 1978) and the first calf to be born here was recorded in the region of Jindřichův Hradec in 1974 (Andreska 1988).

Two core areas of this species' permanent occurrence were gradually established in this country (Anděra and Hanzal 1995). The first was located in the eastern part of the region of Třebon and its surroundings, i.e. in a $20 \mathrm{~km}$ wide strip running from the Novohradské hory Mts. to the Středočeská vrchovina uplands. In winter, elks occurred quite regularly in pine forests in the region of Bechyně, in the surroundings of the Borkovická blata, in the region of Jindřichův Hradec and between Příbraz and Mirochov. In summer, they migrated to the territory of PLA Třeboňsko, the wetlands of the Nová řeka Canal and the adjacent pond basin (Homolka 2000). This population died out at the turn of the first decade of the $21 \mathrm{st}$ century (Šustr, Kašperské Hory, pers. comm. 2010). The last area in the Czech Republic where the Eurasian elk is considered to have occurred permanently is located on the right side of the Lipno Dam and was usually delimited by the border with Austria in the south, by the right bank of the dam in the north, by the former village of $\mathrm{Ka}$ pličky in the east, and by a settlement called Svatý Tomáš in the west. This area extends over approximately $100 \mathrm{~km}^{2}$ and elks shelter here throughout the entire year (Homolka 1998; Homolka 2000; Anděra and Červený 2009).

Sufficient feeding grounds and minimum disturbance are existential conditions for the occurrence of the Eur- asian elk. The animals prefer wet marshy forests in lowlands and uplands, but avoid steep slopes. The carrying capacity of a given area is one of the limiting factors. Most important tree species for them are the goat willow (Salix caprea), alder buckthorn (Frangula alnus) and Scots pine (Pinus silvestris) (Homolka 1998). There is competition for food between elks and deer, especially the red deer, whose presence may be another limiting factor for the occurrence of Eurasian elk (Homolka 2000).

\section{Data Collection}

Questionnaires are the main source of data on the occurrence of Eurasian elk and red deer. In the periods 1991-1992 and 2005-2006, and for the elk also in 2009-2010, in cooperation with the Ministry of the Environment of the Czech Republic, these were submitted to traditional hunting associations within the Czech-Moravian Hunting Association, leased hunting districts of LČR, owners and tenants of other hunting districts including Vojenské lesy a statky ČR (Military Forests and Farms of the Czech Republic), regional offices of AOPK ČR (Agency for Nature Conservation and Landscape Protection of the Czech Republic), and administrative autorities of large-scale protected areas (PLAs and NPs). In case of the elk, further sources of information involved literature, observations by various zoologists and game keepers, and observations made within Mapping of Mammals in the Czech Republic conducted by www. biolib.cz (Anděra and Hanzal 1995; Anděra and Červený 2009). The data from the sources mentioned above were interpreted using a basic map of hunting districts. The structure and form of the questionnaire gave three options for the occurrence of the focal species: permanent occurrence, occasional occurrence and rare occurrence. Occurrence of the Eurasian elk was divided solely into permanent and occasional, the latter also involving observations of migrating individuals. For this reason, the analysis used data on elk from 2005-2009, which are sufficiently comprehensive and still relatively recent. Data on the absence (not to be confused with "no data") of the focal species in a given area are available for red deer from 2005-2009 and for Eurasian elk from 2006-2009. Questionnaires from 2005 and complementary data from the period 2005-2009 covered 78\%, while questionnaires on the Eurasian elk from 2009 covered merely $26 \%$ of the territory. Hunting districts where questionnaires were not completed and submitted were excluded in order to prevent them distorting the analysis. Polygons of hunting districts were used as the basic spatial units for assessing the spatial distribution of the focal species. As opposed to hunting districts, military areas and national parks are significantly larger. To keep the sizes of all the units assessed comparable, military areas and national parks were divided by their areas. The data on the occurrence of both focal species were expressed in a total 6056 polygons. Each polygon in a hunting district was also assigned basic characteristics of its conditions, which were 
used to assess the requirements and preferences of the species. The following variables were selected as appropriate indicators of the quality of these conditions:

\section{Abiotic Factors}

Altitude - expressed as the mean altitude above sea level of hunting districts (source data DEM SRTM $100 \times 100 \mathrm{~m}$ )

Vertical heterogeneity - expressed as a standard deviation of altitude within hunting districts (source data DEM SRTM $100 \times 100 \mathrm{~m}$ )

\section{Habitat Factors}

Type of habitat - expressed as the percentage of individual classes of land cover according to CORINE Land Cover 2006 (EEA 2009) within hunting districts. The classes of land cover subject to assessment were aggregated into the following categories:
1. urban land
2. orchards and gardens
3. arable land
4. meadows and pastures
5. heterogeneous agricultural land
6. coniferous forests
7. deciduous and mixed forests
8. natural non-forested areas
9. wetlands
10. water bodies

\section{Factors of Anthropogenic Disturbance}

Road density, expressed as the length of all communications per hectare within a hunting district.

\section{Factors of Landscape Structure}

Land cover diversity - expressed using Shannon diversity index.

Heterogeneity of land cover - expressed as the number of patches of land cover.

\section{Hunting Data}

Further data were provided by the Czech Statistical Office, which was acquired as part of the statistical research carried out by the Ministry of Agriculture (annual report on hunting districts, on populations of game, and hunting) and the Ministry of the Environment (annual report on hunting districts, populations of game and hunting in national parks). The mentioned annual reports on hunting districts, populations of game and hunting supplied information on game management in the given period (1 April of a given year - 31 March in the following year). To assess the sizes of game populations, the present study counts were compared with the values of the minimum viable population of game in spring.

\section{Statistical Analysis}

We determined how the hunting districts with particular occurrence statuses differed in terms of altitude,

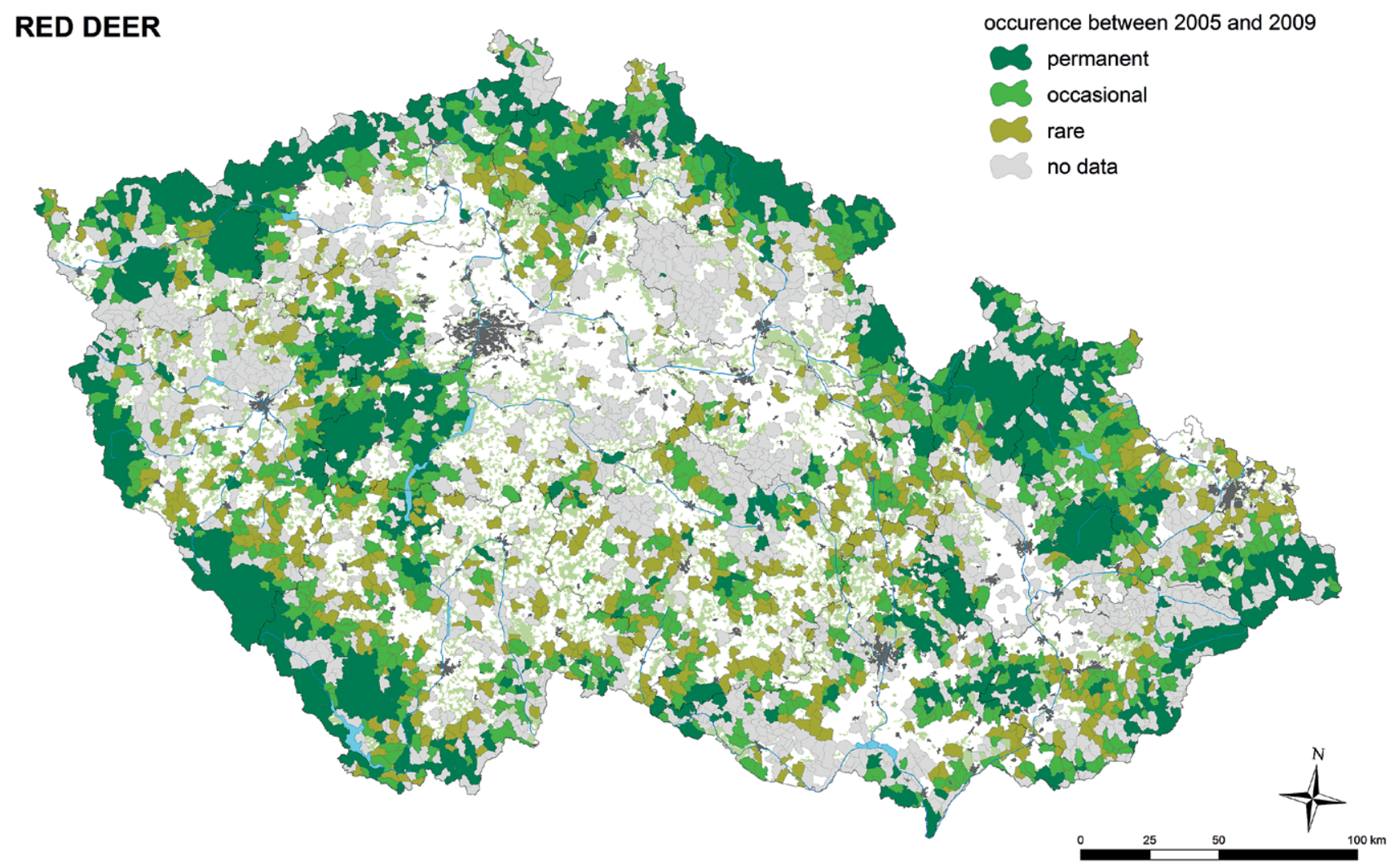

Fig. 1 Distribution of red deer in the Czech Republic between 2005 and 2009. 
vertical heterogeneity, road density, number of land cover categories and Shannon diversity index, using Kruskal-Wallis ANOVA in STATISTICA program. Kruskal-Wallis ANOVA is a nonparametric method used to compare many groups (StatSoft 2001).

To find the relationship between the percentages of the different land cover categories in hunting districts and the recorded occurrence status we used canonical correspondence analysis (CCA) computed using CANOCO for Windows (Ter Braak and Šmilauer 2002). CCA is a direct (constrained) method of unimodal ordination directly displaying the relationship between the variables analyzed (Lepš and Šmilauer 2003).

\section{Results}

\section{Red Deer}

According to the data based on questionnaires from 2005 , the red deer occupies an area $42.42 \%$ of the size of this country (see Fig. 1). As the questionnaires were completed and submitted for assessment from only $77.8 \%$ of the country, the number is not entirely accurate. Quantifying this species occurrence only in areas for which data are available, we reach a figure of $54.52 \%$ of the area of this country. Permanent occurrence is reported in $24.03 \%$ of the area covered and $18.69 \%$ of the total area of this country, occasional occurrence in $17.16 \%$ (13.35\% respectively), and rare occurrence in $13.33 \%$ (10.37\% respectively).

The most significant areas for this species are in border mountains. In the interior of this country, a population of red deer inhabits the region of the Brdy, Ždárské vrchy, Drahanská vrchovina Uplands, Ždánický les and Chrriby. Another population in the lowlands of Soutok near Lanžhot is also significant. The resulting map more precisely delimits the range of this species in this country than graticule based zoological mapping.

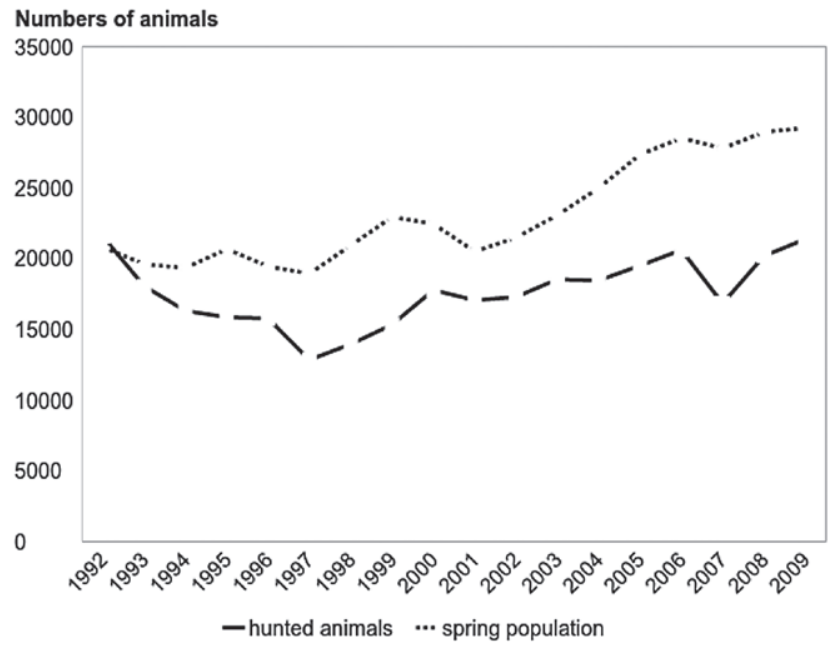

Fig. 2 Red deer (Cervus elaphus) game management results for 19922010 (source: Czech Statistical Office). Numbers of animals killed and estimated minimum viable population in spring.
The census of minimum viable populations in spring reports 20,841 animals in 1992, compared to 26,824 animals in 2005 (data from March 2006), and 29,895 animals in 2009 (data from March 2010). The populations are obviously increasing (by $11.4 \%$ since 2005 and even $43.4 \%$ since 1992) (Fig. 2). As the data were supplied by hunting associations, they are considered to be rough estimates, both of the trend and the actual numbers.

\section{Habitat Preferences}

The core areas for red deer populations are in forested mountain ranges. The analyses of habitat preferences depict the trend of a more frequent permanent occurrence

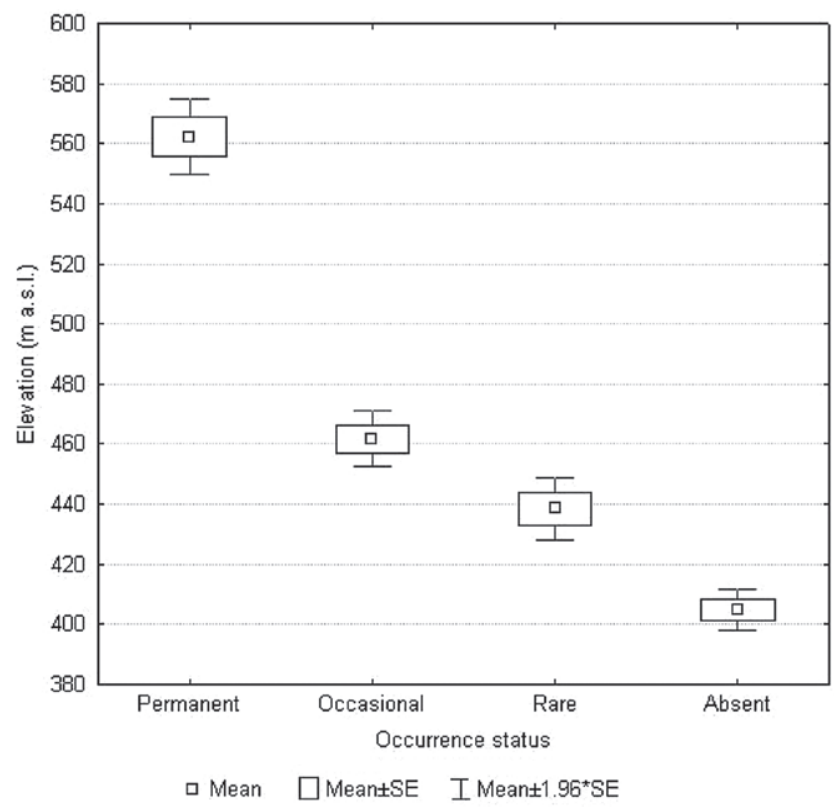

Fig. 3 Mean altitudes of hunting districts with particular categories of the red deer occurrence displayed as boxplots.

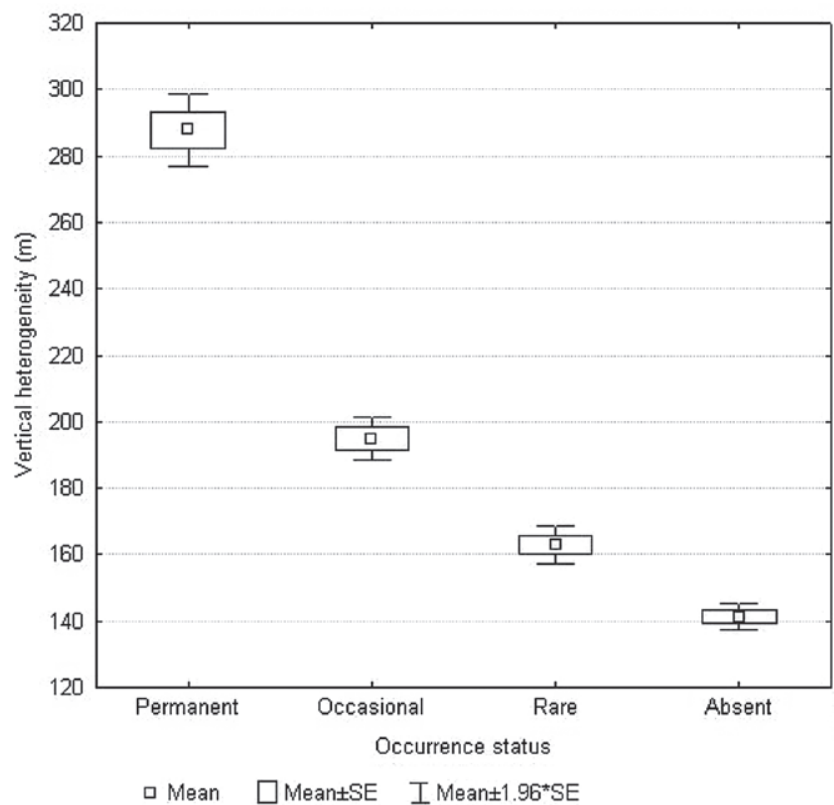

Fig. 4 Mean vertical heterogeneity of hunting districts with particular categories of the red deer occurrence displayed as boxplots. 


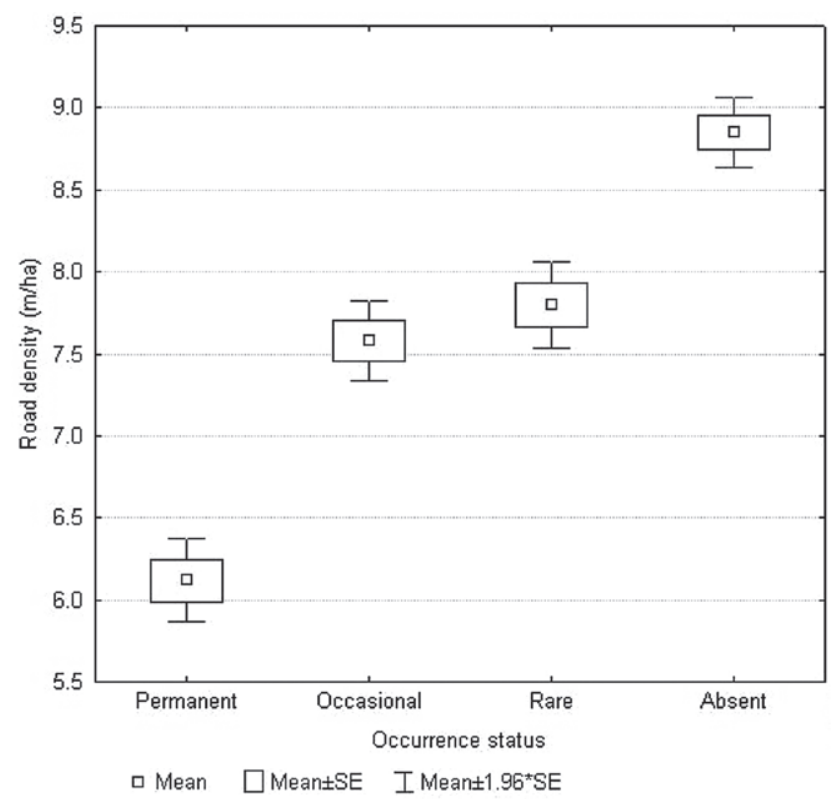

Fig. 5 Mean lengths of roads (meters per hectare) in hunting districts with particular categories of the red deer occurrence displayed as boxplots.

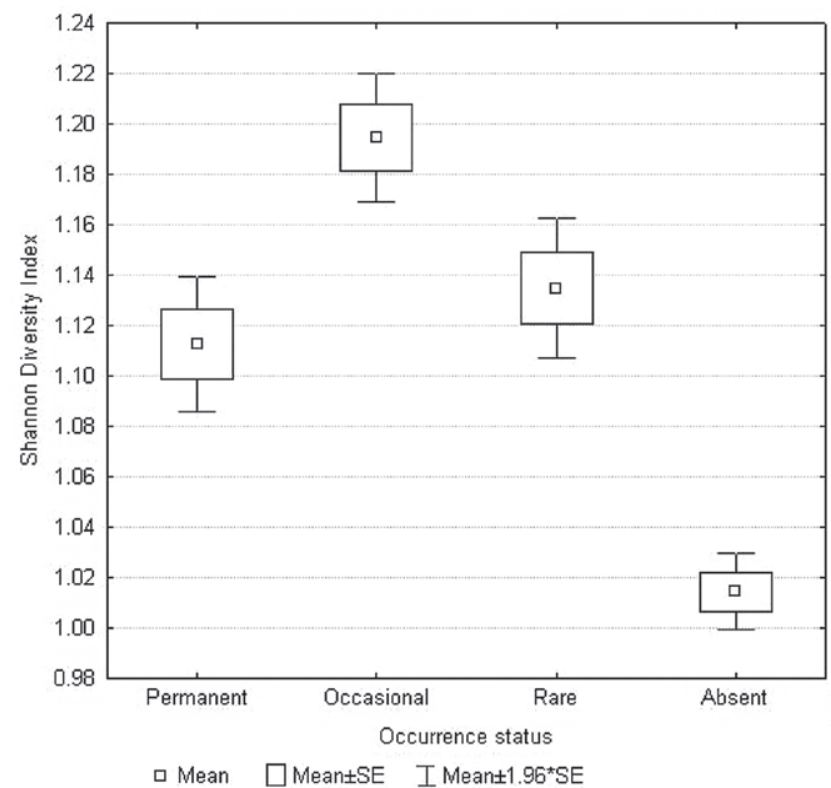

Fig. 7 Land cover diversity (expressed in terms of the Shannon diversity index) in hunting districts with particular categories of red deer occurrence displayed as boxplots.

at high altitudes (Kruskal-Wallis test: $\mathrm{H}(3, \mathrm{~N}=4566)=$ 512.5707, ${ }^{* * *} \mathrm{P}<0.001$ ) (Fig. 3).

Mountain areas where red deer permanently occur in the Czech Republic have a pronounced vertical heterogeneity (Kruskal-Wallis test: $\mathrm{H}(3, \mathrm{~N}=4566)=899.1497$, $\left.{ }_{* * *} \mathrm{P}<0.001\right)$ (Fig. 4).

Permanent occurrence of red deer is typically associated with low anthropogenic disturbance measured in terms of a low density of roads $(\mathrm{m} / \mathrm{ha})$ (Kruskal-Wallis test: $\left.\mathrm{H}(3, \mathrm{~N}=4566)=241.0102,{ }^{* * *} \mathrm{P}<0.001\right)$ (Fig. 5).

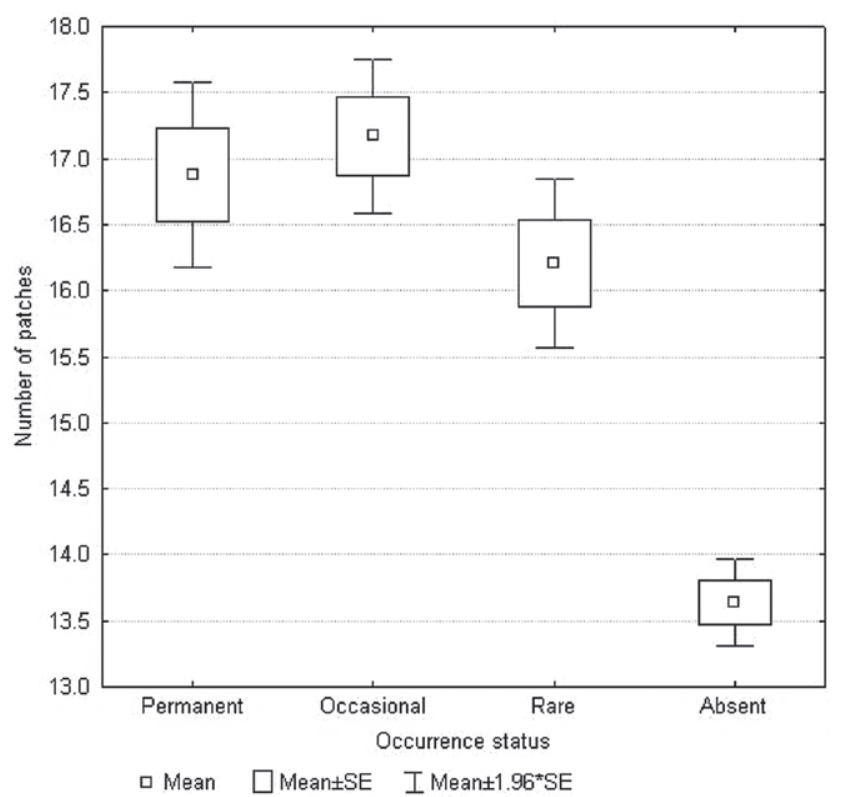

Fig. 6 Land cover heterogeneity expressed in terms of the mean number of patches in hunting districts with particular categories of red deer occurrence displayed as boxplots.

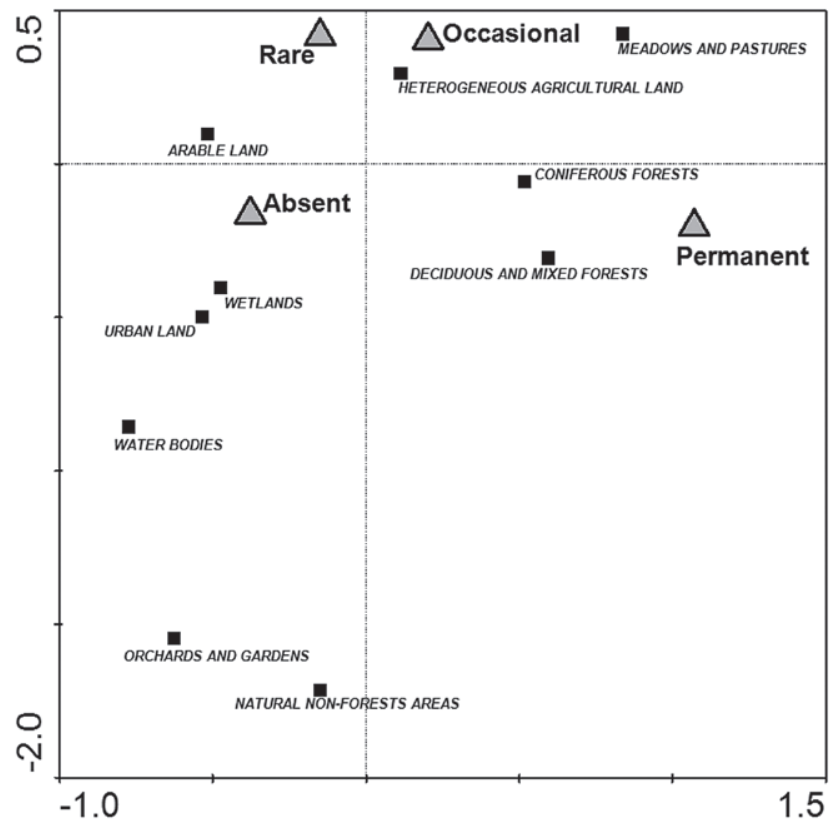

Fig. 8 Canonical correspondence analysis of land cover classes at locations where the occurrence status of red deer differ.

Areas with red deer occurrence are typically the more heterogeneous hunting districts with a larger number of patches (Kruskal-Wallis test: $\mathrm{H}(3, \mathrm{~N}=4566)=199.3514$, ${ }_{* * *} \mathrm{P} \leq 0.001$ ) (see Fig. 6), more land cover classes (Kruskal-Wallis test: $\left.\mathrm{H}(3, \mathrm{~N}=4566)=165.346,{ }^{* * *} \mathrm{P} \leq 0.001\right)$ and generally higher diversity of different kinds of land cover expressed in terms the Shannon diversity index SHDI (Kruskal-Wallis test: $\mathrm{H}(3, \mathrm{~N}=4566)=170.8695$, ${ }^{* * *} \mathrm{P} \leq 0.001$ ) (Fig. 7).

The canonical correspondence analysis (Fig. 8) revealed significant differences in the share of individual 
land cover classes in hunting districts with different categories of red deer occurrence $\left({ }^{* *} \mathrm{P}<0.01\right)$. Areas with permanent occurrence of red deer are generally characterized as those with a larger cover of deciduous and coniferous forests and meadows. Areas where the species is absent are mainly arable or urban land, or mainly covered by water bodies or wetlands.

\section{Eurasian Elk}

In the last period under review (2006-2009), the occasional occurrence of elk was reported inn $1.49 \%$ and permanent occurrence in $0.69 \%$ of this country's area (Fig. 11). Questionnaires relating to the period 20062009 were completed and submitted from only a quarter of the country (26.52\%) and thus are fragmented. For this reason, the data for 1993-2005 is the most precise information on the current distribution of this species as these were collected from $77.8 \%$ of the country's area. During 1993-2005, the Eurasian elk was recorded occurring permanently on $0.41 \%$ and occasionally or migrating in $5.73 \%$ of the country (Fig. 10). Compared to the data for 1985-1992, when permanent occurrence was recorded in $0.33 \%$ and occasional or migratory in $9.75 \%$ of the country (Fig. 9), the total area of permanent occurrence of this species increased by $24 \%$, whereas, the area of occasional and migratory occurrence dropped by $41.2 \%$. The data for 2006-2009 imply, however, that the area of Eurasian elk permanent occurrence increased by $68.3 \%$ over that in the preceding period (doubled compared to 1992). This increase mainly reflects the extended home range of the population in the Šumava Mts. As the Eurasian elk in the region of Třebon became extinct, the above numbers are currently not valid.

Migrating individuals occurred frequently anywhere in the past. Their numbers though have dropped significantly. In recent years, elks occupied only the right bank of the Lipno Dam and PLA Třeboňsko, but this population died out in 2010. In the east of the Šumava Mts., this species currently occurs in the surroundings of the village Dolní Drkolná. The range of its permanent occurrence spreads over the entire right bank of the dam and reaches its left bank in the south, particularly in the surroundings of Frymburk. Compared to previous years, its distribution has changed range most significantly in terms of expanding to the south in NP Šmmava, where elks occur in an area extending to the village of Stožec. In the recent past, these animals could also be seen in some areas adjacent to those of permanent occurrence both in the Šumava and in the region of Jindrichův Hradec. This was most probably due to individuals leaving permanent populations. There are also records of elk occurring in the Českomoravská vrchovina Uplands and the north of Bohemia. However, these could relate to migrating animals. Maps in Figs. 9-11 record elk occurrences in two periods that are comparable in terms the time and intensity of data collection. They indicate a decrease in the

\section{EURASIAN ELK \\ Enownet}

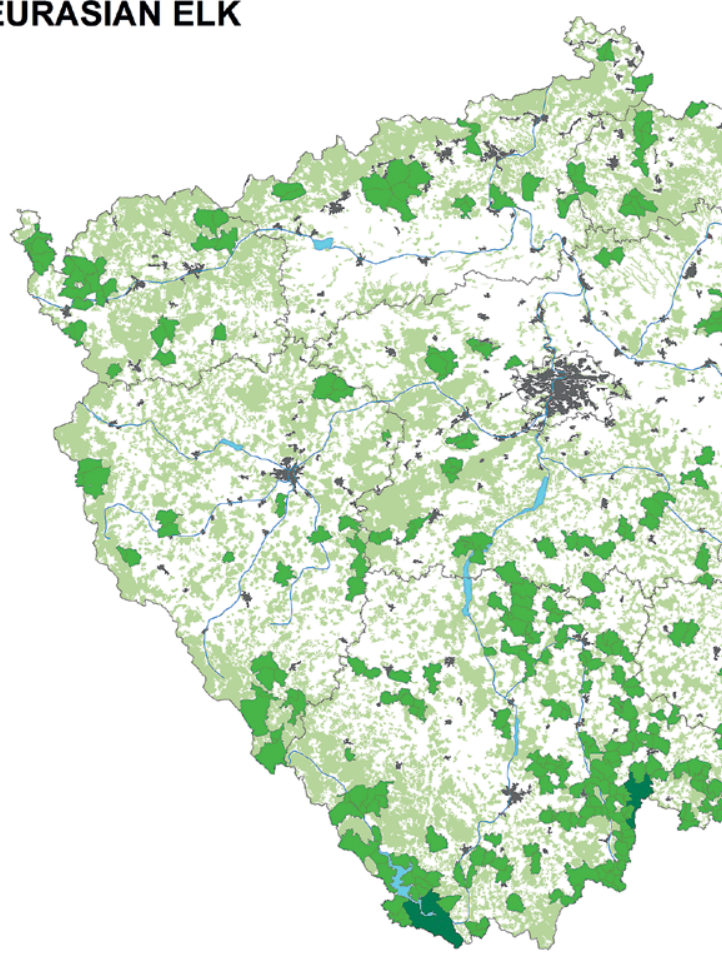

occurence before 1992

3 permanent

3 occasional

Fig. 9 Map showing the distribution of Eurasian elk in the Czech Republic in 1985-1992. 


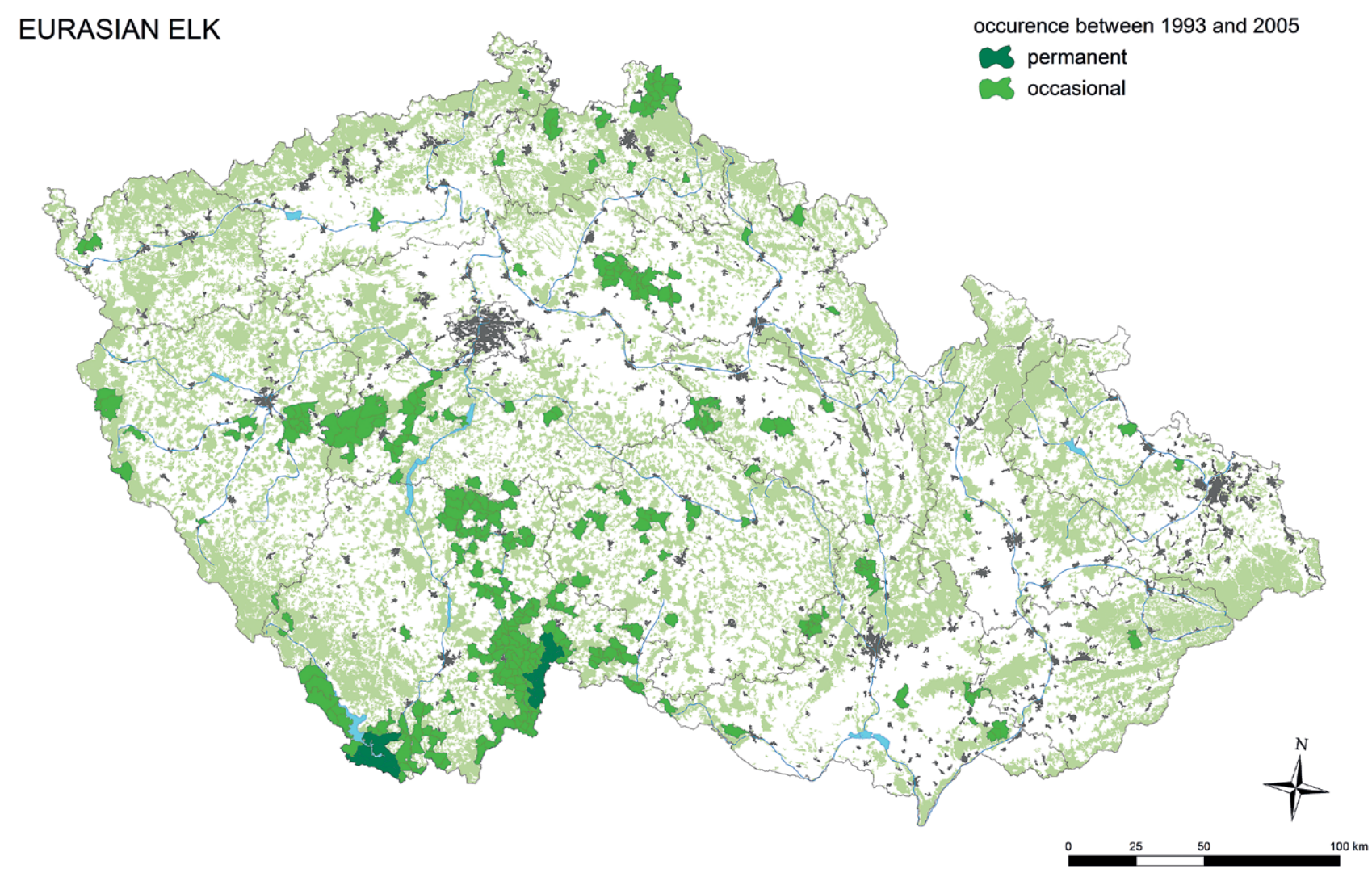

Fig. 10 Map showing the distribution of Eurasian elk in the Czech Republic in 1993-2005.

\section{EURASIAN ELK}

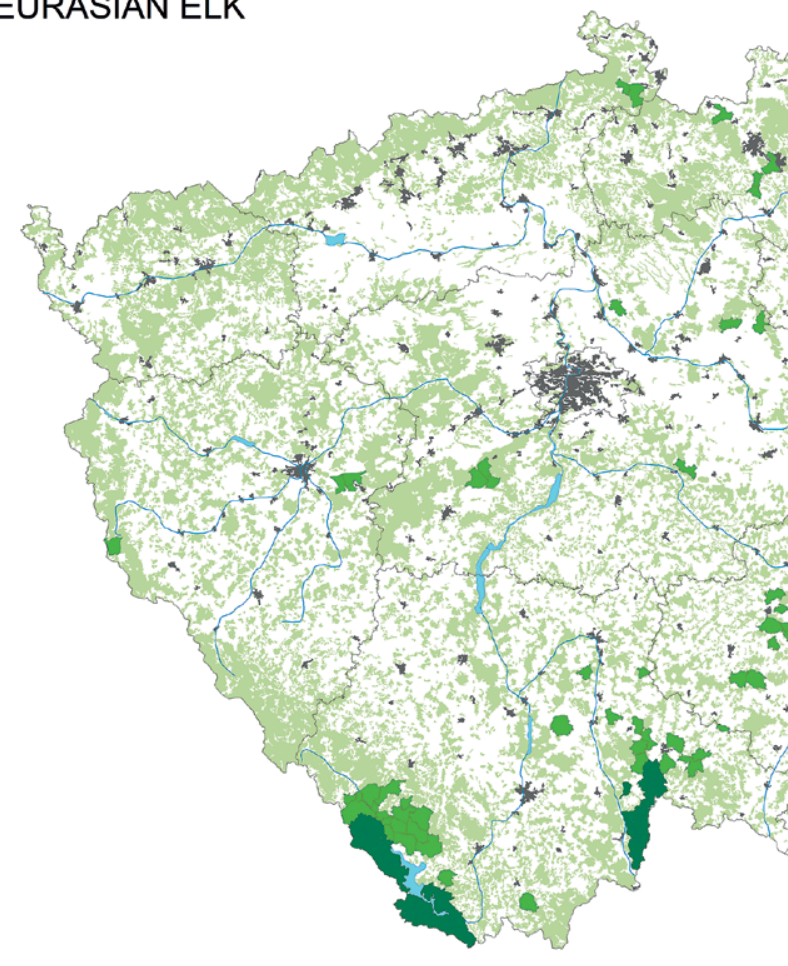

occurence between 2006 and 2009

4 permanent

3 occasional

Fig. 11 Map showing the distribution of Eurasian elk in the Czech Republic in 2006-2009. 
number of animals observed migrating, mainly at Podkrušnohoří and in the north of Moravia. In addition, a permanent micropopulation in the region of Nymburk has also disappeared. These negative trends continued in the last period reviewed (2005-2009) and resulted in the disappearance of the permanent population in the region of Třeboň in 2010.

From 1993, the number of elks recorded in the spring minimum viable population (published by the Czech Statistical Office) in the Czech Republic has varied between 13 and 60 animals. On average, the population of Eurasian elk in the Czech Republic is 28 animals. This data, however, is very likely to be inaccurate, unreliable and of low informative value. The number of 50 to 60 animals is completely misleading.

\section{Habitat Preference}

Hunting districts with the permanent occurrence of Eurasian elk are mostly located at high altitudes (Kruskal-Wallis test: $\left.\mathrm{H}(2, \mathrm{~N}=6056)=53.06290,{ }^{* * *} \mathrm{P}<0.001\right)$.

There is a strong correlation between vertical heterogeneity of the terrain and altitude $(r=0.574 ; \mathrm{N}=6056$, $\left.{ }^{*} \mathrm{P}<0.05\right)$, which is reflected in the occurrence of red deer (Fig. 3). The situation with Eurasian elk is obviously distinct (Fig. 12), which implies that, within the range of its distribution, elk prefers a rather flat terrain, which is not the case for red deer. The vertical heterogeneity at locations at high altitudes with permanent or occasional occurrence of Eurasian elk is not high, which is reflected vertical heterogeneity of the districts where elk are hunted being lower than what is normal for locations at that altitude (Fig. 13).

Areas with permanent occurrence of the Eurasian elk are characteristic with low anthropogenic disturbance

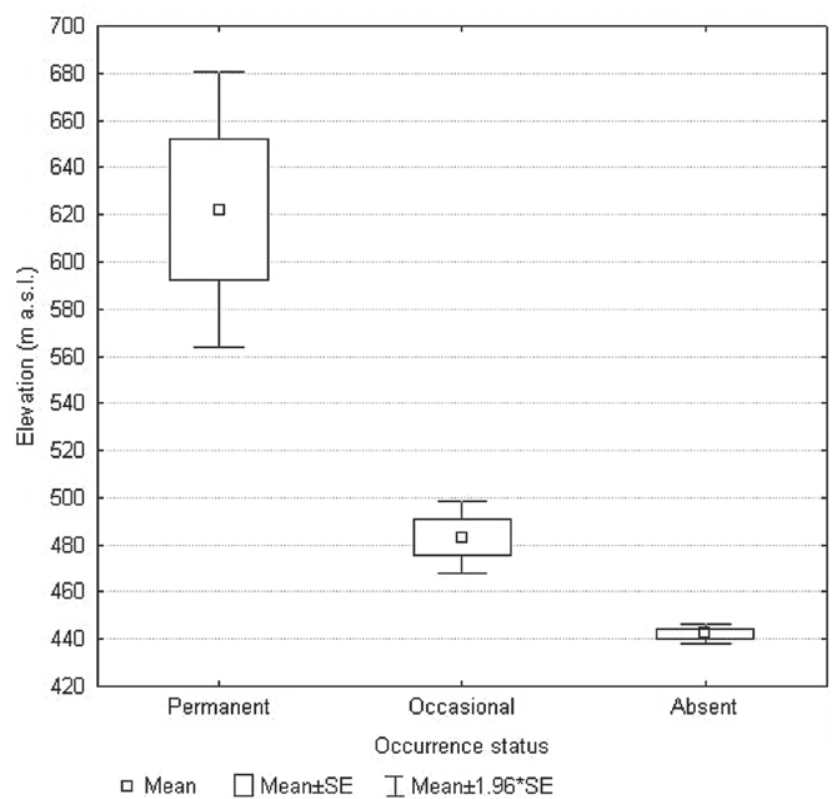

Fig. 12 Mean altitude of the hunting districts with particular categories of Eurasian elk occurrence displayed as boxplots. expressed as road density (Kruskal-Wallis test: $\mathrm{H}$ (2, $\left.\mathrm{N}=6056)=10.67066,{ }^{* *} \mathrm{P}<0.01\right)($ Fig. 14).

Areas of permanent occurrence of the Eurasian elk have a significantly lower land cover diversity (expressed in terms of Shannon's diversity index) (Kruskal-Wallis test: $\left.\mathrm{H}(2, \mathrm{~N}=6056)=12.18477,{ }^{*} \mathrm{P}<0.01\right)$ (Fig. 15). Similarly, the heterogeneity of land cover in hunting districts with the permanent occurrence of this species, expressed as an average number of patches and average number of land cover classes, is also lower in these areas (Kruskal-Wallis test: $\mathrm{H}(2, \mathrm{~N}=6056)=26.54428$; ${ }^{* * *} \mathrm{P}<0.0001$, resp. Kruskal-Wallis test: $\mathrm{H}(2, \mathrm{~N}=6056)$

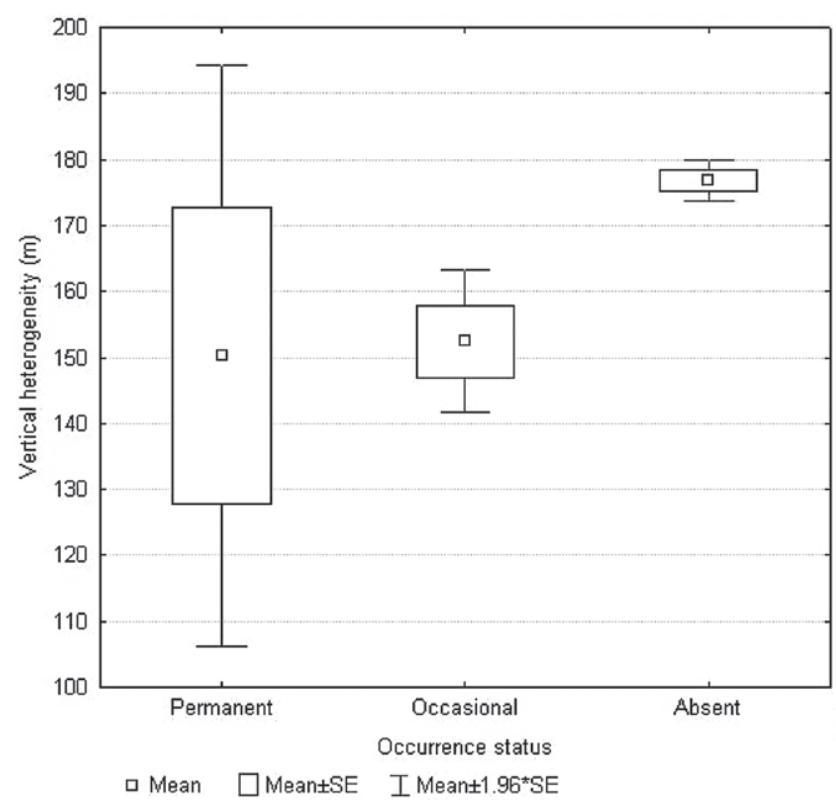

Fig. 13 Mean vertical heterogeneity in hunting districts with particular categories of Eurasian elk occurrence displayed as boxplots.

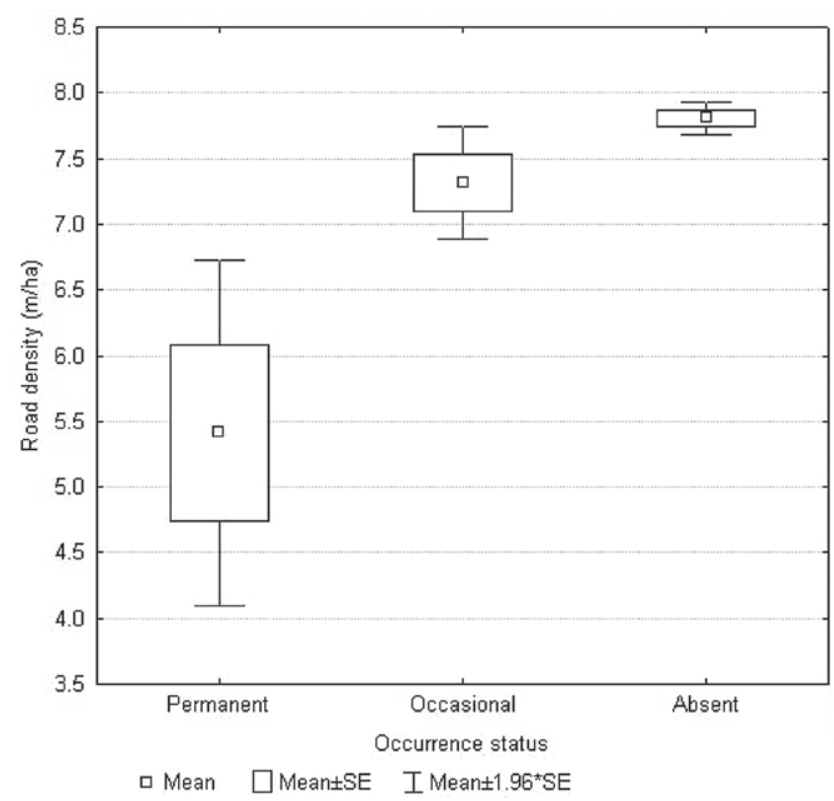

Fig. 14 Mean road density (meters per hectare) in hunting districts with particular categories of Eurasian elk occurrence displayed as boxplots. 


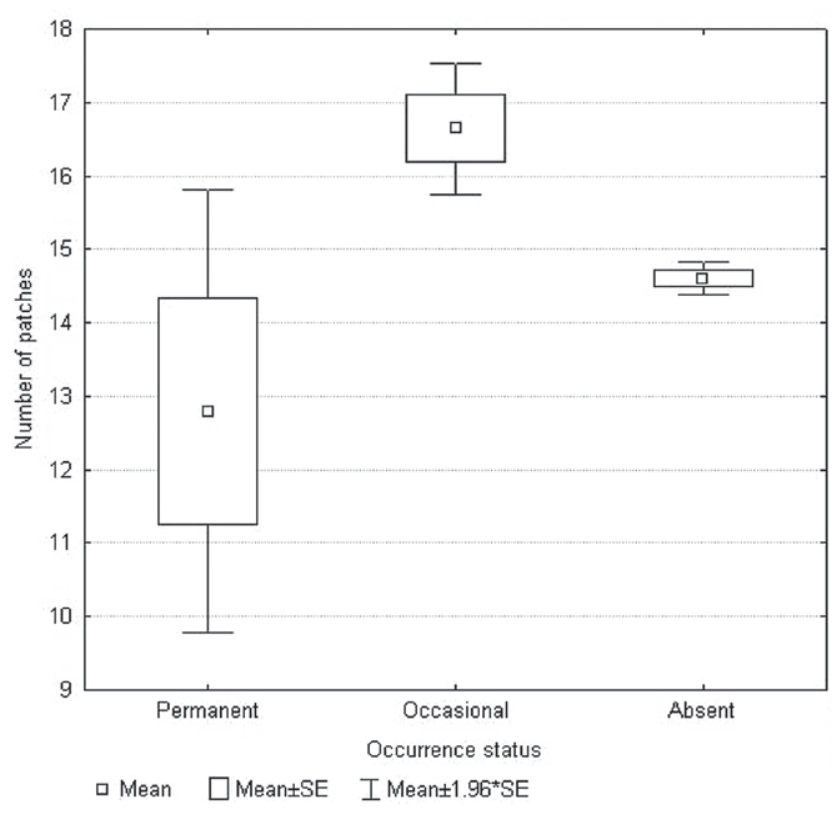

Fig. 15 Land cover heterogeneity expressed as the mean number of patches in hunting districts with particular categories of Eurasian elk occurrence displayed as boxplots.

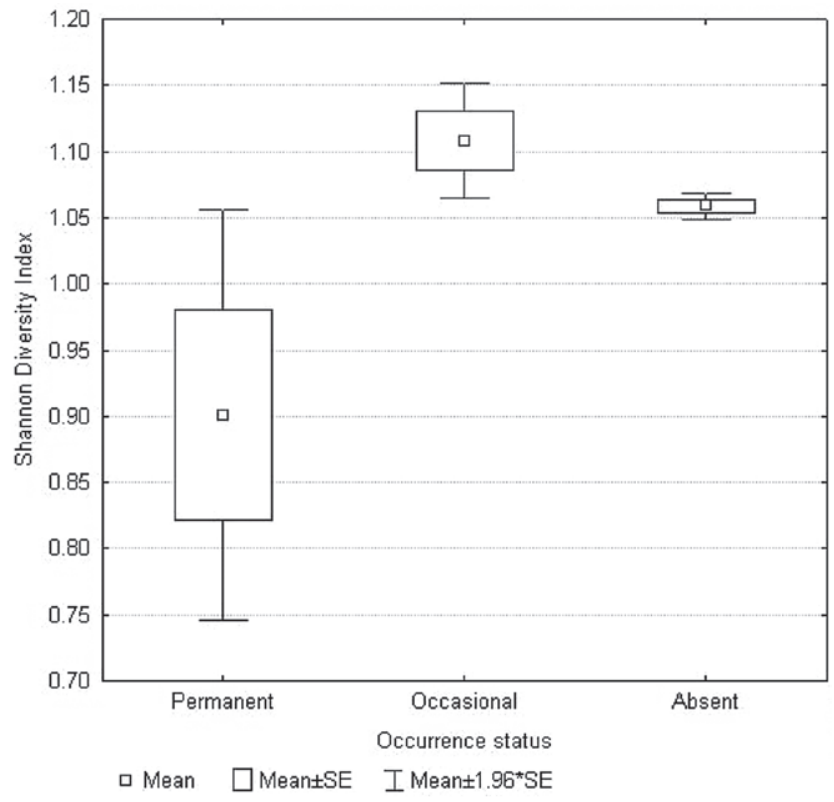

Fig. 16 Land cover diversity (expressed in terms of Shannon's diversity index) in hunting districts with particular categories of Eurasian elk occurrence displayed as boxplots.

$\left.=52.36012 ;{ }^{* * *} \mathrm{P}<0.0001\right)($ Fig. 16)). Thus, Eurasian elk are markedly different from red deer, which prefer areas with high heterogeneity and diversity of land cover.

Canonical correspondence analysis (Fig. 17) revealed significant difference in the share of individual classes of land cover in hunting districts with different occurrences of Eurasian elk ( $\left.{ }^{* *} \mathrm{P}<0.01\right)$. Areas with permanent occurrence characteristically have a higher proportion of coniferous forests, pastures and water bodies, whereas those where the species is absent typically have a high proportion of arable and urban land, and deciduous forest.

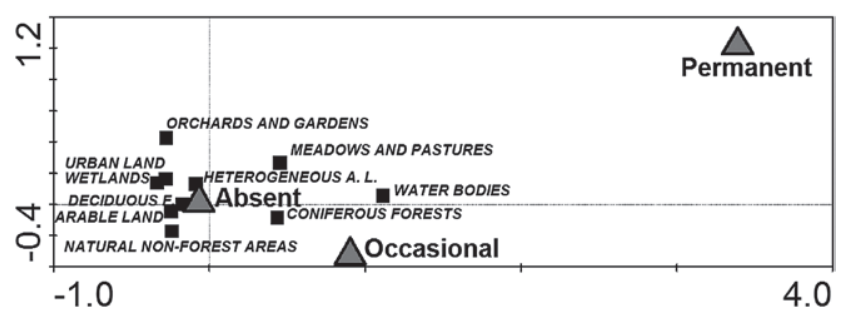

Fig. 17 Canonical correspondence analysis of land cover classes at locations with different occurrence of Eurasian elk. (Abbreviated HETEROGENEOUS A. L. = heterogeneous agriculture land, DECIDUOUS F. = deciduous and mixed forests).

\section{Discussion}

\section{Red Deer}

Maps of red deer abundance in the Czech Republic based on the distribution of this species in hunting districts indicater substantially lower numbers than the data of Anděra and Červený (2009), which are based on graticule based maps, which are significantly more precise. Nevertheless, these data indicate a gradual increase in the distribution of this species.

Two publications, Anděra and Hanzal (1995) and Anděra and Červený (2009), who use a graticule for the spatial division of their map, provide the best data on the distribution of red deer in the Czech Republic over the past 20 years. The Czech Republic is well covered in both cases. Questionnaires on the distribution of this species were completed and submitted from $82.2 \%$ of the territory in 1991-1992 and $93 \%$ in $2005-2006$. The data for the first period records 306 squares of permanent occurrence and 214 of occasional occurrence of the red deer. Two squares of rare occurrence were excluded from data processing in the first period as the data were not considered reliable. The figures for the second period (2005-2006) records 317 squares of permanent and 142 squares of occasional occurrence of the red deer. This indicates no dramatic changes in either the extent or the geographic distribution. In the period 2005-2006 there was a decrease in the number of squares of occasional occurrence by more than a third (Andèra and Červený 2009). It should be noted, however, that the original data for the second period also included rare occurrences of this species, recorded in 104 squares of the grid, which were excluded from the final assessment. The exclusion of the two squares with unreliable data in the period 1991-1992 is considered justified. In the second period, however, there were 104 squares of rare occurrence (data submitted by approximately 600 hunting associations). Data coming from such a large number of squares are less likely to be unreliable and their exclusion from the assessment significantly distorts the distribution of red deer in the Czech Republic. If we include data on rare occurrences then a comparison of both periods under review gives a different result concerning the distribution of red deer in the Czech Republic: no substantial changes 
in the areas of permanent occurrence of this species with them permanently occurring in $46.6 \%$ of this country's area; areas of occasional occurrence decreases by approximately a third to $20.9 \%$; but the number of squares with reported rare occurrence increases 52 times from $0.29 \%$ in 1991-1992 to $15.3 \%$. If the figures on occasional and rare occurrence are taken as a single category, the area of such a category increases by $13.9 \%$ between the two periods and red deer occurs occasionally or rarely in $36.2 \%$ of the country. Generally, the area of any occurrence of this species has been increasing. This assumption is also supported by growing numbers of practically all wild eventoed ungulates subject to game management. Red deer is currently even considered as overpopulated, which is, according to a number of authors, due to inappropriate processing of hunting statistics and hunting plans (Kamler 2010; Kamler and Plhal 2010; Marada 2010; Pfeifer 2010). The growing numbers of red deer are also apparent from the data provided by the Czech Statistical Office (Fig. 2), which are considered by certain sources as $30 \%$ underestimated (Pfeifer 2010). The Ministry of the Environment of the Czech Republic has already responded to the situation by issuing Guidelines for State Administration Bodies to Reduce Populations of Hoofed Game in the Czech Republic of 4 July 2008 (Ref. No. 23485/2008 $16200)$. It is thus not surprising that red deer migrate to new areas and often makes use of agricultural land with a higher proportion of fields and roads. A mature maize field surprisingly offers a quieter environment with an even better food supply than a forest full of mushroom pickers (Pfeifer 2010).

\section{Red Deer Habitat Preferences}

The fact that this study indicates that the red deer occur mainly at high altitudes in the Czech Republic is not determined by their preference for a montane or sub-montane environment. Forest vegetation providing sufficient cover for game often is a more important factor than food supply in determining the actual distribution of this species (Borkowski 2004). High altitude areas are covered with extensive forests in this country. The red deer population density is highest in lowland forests as they have a higher carrying capacity (Prokešová et al. 2006), which proves that high altitude areas are not its naturally preferred habitat. As the population density is largely affected by game management practices, the interpreted data should be approached with certain prudence. Still, altitude and the related choice of habitats may locally play a role. Čejka (1998) reports that the population density of red deer increases with increase in altitude, possibly because this species prefers the southern sides of mountain ridges as they provide a more favourable microclimate and a good view that enables them to respond faster to potential threats.

More frequent permanent occurrence at high altitudes is also related to the occurrence there of a more pronounced vertical heterogeneity, which is highly cor- related with altitude $\left(\mathrm{r}=0.574 ; \mathrm{N}=6056,{ }^{\star} \mathrm{P}<0.05\right)$. The vertical heterogeneity in hunting districts with a permanent occurrence of red deer at a given altitude is slightly higher than what we might expect. This suggests that this species, unlike Eurasian elk, does not avoid vertically heterogeneous terrain.

The distribution range of red deer is obviously of a relict or anthroporelict character in Central Europe as this species has been forced out into marginal and less inhabited parts of the country where there are still large areas of forest and a lower road density. The data do not allow a direct assessment of the negative effects of road density on red deer populations. Nevertheless, the negative effects of road density and the related drop in habitat accessibility are generally accepted (Frair et al. 2008).

The type of vegetation and land cover is important for red deer both as a hiding place and for feeding. This species is generally and naturally understood as forest game (Anděra and Horáček 2005). Non-forest habitats are also important for this species. In Norway, for example, the weight of the deer is positively correlated with the proportion of meadows in the landscape (Mysterud et al. 2002). Suitable habitats with a sufficient carrying capacity affect the fitness of animals even in subsequent generations (McLoughlin et al. 2008). That red deer favour pastures is also reported by Godvik et al. 2009. These authors demonstrate that, in forest habitats containing some forage, there is both an increase in the selection of pastures (i.e., not proportional) and a reduction in the time spent in pastures (i.e., not constant time use) with a decrease in the availability of pastures within the home range. Similarly, Jones and Hudson (2002) report that this species uses the grass/meadow habitat more than expected, while all other habitats are used in proportion to their availability.

In the Czech Republic, the red deer predominantly occurs at high altitudes and from the agricultural point of view less important areas, where the proportion covered by pastures has significant increased in the past 20 years (Romportl et al. 2010). This may be one of the factors causing the mentioned increase in the red deer population (see Fig. 2 - game management in 1992-2009).

Higher SHDI values in areas with reported occurrence of red deer support the presumption that it is an ecotonal species adapted to feeding on a mixed diet of browse and graze (Clutton-Brock et al. 1982).

\section{Eurasian Elk}

The number of migrating individuals is currently much lower than in the past, when they could be observed practically anywhere (Anděra and Horáček 2005). At the end of the 1990s, Homolka (1998) stated that 30-50 animals permanently occurred in the Czech Republic. Later, the area of occasional occurrence of Eurasian elk diminished nearly by $85 \%$ as opposed to the turn of 1980 s, which presumably relates to the predicted negative development of the population in Poland (Raczyński 2008), 
where most of the migrants came from. It is reflected in the fact that there has been a significant reduction in the number of migrating animals in Moravia, in the area of the Krušné hory Mts. and the České středohoří uplands. Nevertheless, elks still migrate from the area of the Orlické hory Mts. moving south-westwards into south Bohemia. Migration of these animals from Poland may be related to their tendency to follow significant topographic elements in the landscape, which in this case may be the Nysa Kłodzka River (Andersen 1991; Ball et al. 2001; Rolandsen et al. 2010). The lower numbers of occasional and migratory occurrences are, to a certain extent, affected by incomplete data acquired within the last reporting period, but may still indicate a certain development.

In the early 1990s, when the Czech Republic opened its border with neighbouring countries, elks found a new way to the south and began to spread and search for new areas to settle. Austrian administration responded to the presence of this new species by issuing permits to shoot three animals (Ševčík 1994; Mrlík 1998). The administration of PLA Třeboňsko responded immediately to the issuing of these permits by sending a letter to the Provincial Government of Lower Austria, pleading for assistance and addressed various nature conservation and zoological institutions. This resulted in a number of negotiations the outcome of which was that elk would only be hunted in Austria in exceptional circumstances or prevented altogether (Ševčík 1994). Homolka and Heroldová (1997) state that the Eurasian elk is already listed in Austria as game subject to protection throughout the year. A permit may be granted to hunt this animal if it can be proved it caused damage. In Germany, the Eurasian elk is considered as a species not natural to the cultural landscape and is hunted (Homolka and Heroldová 1997). This species has always been protected all year round in the Czech Republic under Act No. 114/1922 Coll., where it is listed in the category of specially protected species as a strongly threatened species. Hunting it is still possible under a Decree of the Ministry of Agriculture No. 134/1996 Coll. in the period from 1 August to 31 December, but only upon a permit issued by the Ministry of the Environment. No such permit has ever been issued in the Czech Republic. However, at least 5 animals have been illegally hunted since 1976 (Anděra and Kokeš 1978). Poaching is generally reported as one of the most frequent causes of death in Eurasian elk (based on data from Bohemia, Slovakia, Austria and Germany) and makes up 36\% of the death rate (Homolka 2000; Hutr 2004). The first rank in these sad statistics is held by road kills, i.e. 38\% (Anděra and Kokeš 1978; Homolka 2000; Hutr 2004). Three cases were reported from Bavaria in 2007 (Märtl 2009). Also in the Czech Republic an elk was hit by a car on expressway I/35 near Hodkovice nad Mohelkou on 7 April 2009 (Suchánková 2009).

The increasing number of areas of permanent occurrence is interesting. It may have been due to a reduced number of individuals migrating to Austria. Elks began to spread into Austria in the early 1990s, when the barriers along the Czech borders were removed. This invasion only lasted for two years. As the animals did not find favourable conditions there, they left, except from the area adjacent to the region of Jindřichův Hradec) (Homolka and Heroldová 1997; Mrlík 1998).

The area of this species' permanent occurrence grew in size mainly on the right bank of the Vltava River and the Lipno Dam, where the number of animals is similar to that in the past. This is the last permanent population of this species in this country. It settled here at the turn of the 1970s and there were 13 animals in 1995 (Homolka 1998); Anděra and Červený (1994) mention 10 to 20 animals. The records based on trails indicate a minimum of 11 animals in 1996 (Homolka 1998). The Lipno population is currently estimated at 10-15 animals; the most accurate census was conducted by game wardens in the Forest District Vyšší Brod who reported 9 individuals (Märtl 2009; Šustr 2010). Extension of the area of permanent occurrence of Eurasian elk into the National Park Šumava is undoubtedly the most significant change. It is documented, for example, by Šustr (2010) and supported by data on animals hit by cars in neighbouring Bavaria (Märtl 2009), but which most probably came from NP Šumava.

Until recently, the region of Třebon was the second area of this species' permanent occurrence in the Czech Republic. The maximum size of this population was estimated at 10-20 animals in the second half of the 1980s (Ševčík 1994). In 1993, the estimates were 3-5 animals (Ševčík 1994) in this population; the same as that estimated by Kuchyňka (1994). Ševčík (1995) further added that the total number of animals occupying the area might have been slightly higher as some animals might not have been observed, particularly in marginal areas. Homolka and Heroldová (1997) estimate the elk population in the region of Třebon to be 10 animals. Unfortunately, more precise data on the occurrence of individual animals is missing for more recent years and permanent occurrence is reported only at PLA Třeboňsko. The last animal probably lived here in the first decade of the 21st century and died in the second half of 2010 (Šustr, Kašperské Hory, pers. comm. 2010).

Other permanent "micropopulations" were recorded in the past, particularly in areas adjacent to Třebon. Mrlík (1996) report about 18 animals on average every year in a large area between Nové Hrady and Veselí nad Lužnicí between 1990 and 1994. From 1991, elk calves were observed in the region of Bechyně, where the number of animals varied between 3 and 5 throughout the year. The number recorded in the Jistebnice region was around 6-8 animals and 5 were reported in the region of Jindřichův Hradec (Homolka and Heroldová 1997). Homolka (2000) also describes permanent occurrence of this species in an area extending from the Novohradské hory Mts. to the Středočeská vrchovina uplands, for which he cites approximately 30 animals. However, there is no more detail on their movements. 
There was a micropopulation of elk in the region of Nymburk, where 1-2 females with calves and a male occupied the area of Forest Districts Dymokury, Kněžice and Roždalovice (Homolka and Heroldová 1997). Data from the first decade of the 21st century state, however, indicates that this population died out before 2004 (Anděra and Červený 2009). There are also areas where permanent occurrence was not considered but females with calves were observed. At the beginning of the new millennium, Hutr (2004) reports several records of this species in the surroundings of Príbram and Brdy, including a female with a calf. The preference of elks for forested areas is presumably related to their timidity. As is the case of the red deer, the Eurasian elk primarily seeks environments that provide good cover. At the home range scale, elks select early seral habitats that provide both food and cover, or primarily cover (MacCraken et al. 1997).

This species' tendency of avoid areas subject to disturbance is clearly indicated in this study by the small percentage of urban land in areas of permanent occurrence and is also reported in substantially less inhabited Finland (Nikula et al. 2004).

Preference for a vertically less heterogeneous terrain is probably due the animal's physical proportions. With its huge body, it is better adapted to flat lake areas in Fennoscandia, northern Russia and Siberia. This preference for less steep terrain compared to the red deer is also reported by Gillingham and Parker (2008).

The macrohabitat analysis revealed that Eurasian elk occurs in areas with a high percentage of coniferous forests in the Czech Republic, which is in accordance with its food requirements, i.e. leaves and shoots of certain tree species, such as Goat Willow (Salix caprea) and Alder Buckthorn (Frangula alnus) (Homolka and Heroldová 1997; Homolka 1998). These trees usually do not form vast and continuous stands but grow in patches in successive stages in meadows, abandoned agricultural land and waterlogged sites. This is where elks seek their food (Homolka 1998). In winter, elks in the Czech Republic prevailingly feed on annual shoots of previously mentioned trees and, among conifers, on pine stands (Homolka 1998). The same food strategy is frequently recorded in other parts of this species' home range (Courtois et al. 2002). Unproven preference for wetlands and deciduous forests is a surprising result. In both cases, this fact may be due to by the nature of the CORINE Land Cover habitat data. The minimum size of a mapping unit determined by the spatially extensive classification of satellite images is $25 \mathrm{ha}$, which exceeds the typical size of wetlands in the Czech Republic. Wetlands are mostly minor enclaves inside a larger matrix and thus are not recorded in the data used. For this reason, this type of habitat is not typically included as an individual class of land cover but more frequently as part of larger coniferous or mixed forest stands or heterogeneous areas with agricultural land and a natural cover of woody species.

\section{Acknowledgements}

The authors would like to acknowledge and express their gratitude to E. Chumanová (The Silva Tarouca Research Institute for Landscape and Ornamental Gardening, Průhonice) for consultations on statistical analyses and J. Pondělíček and J. Rủžička (Ministry of Agriculture, Prague) and J. Císař (Forest Management Institute, Brandýs nad Labem) for providing a digital map of the hunting districts in the Czech Republic.

This research project was supported by the Ministry of the Environment of the Czech Republic from projects No. MSM 6293359101 and VaV SP/2d4/36/08.

\section{REFERENCES}

Anděra M, Červený J (1994) Atlas of Distribution of the Mammals of the Šumava Mts. Region (SW Bohemia). Acta Scientiarum Naturalium Academiae Scientiarum Bohemicae Brno 28: $1-110$.

Anděra M, Červený J (2009) Large mammals in the Czech Republic. Distribution, history and protection. 1 Even-toed ungulates. Národní muzeum, Praha.

Andera M, Hanzal V (1995) Atlas of the mammals of the Czech Republic. A provisional version. I. Even-toed ungulates (Artiodactyla), Lagomorphs (Lagomorpha). Národní muzeum, Praha.

Anděra M, Horáček I (2005) Poznáváme naše savce. 2nd Edition. Sobotáles, Praha.

Anděra M, Kokeš O (1978) Migrace losa (Alces alces L.) v Československu. Časopis Slezského muzea v Opavě (A) 27: 171-188.

Andersen R (1991) Habitat deterioration and the migratory behaviour of moose (Alces alces L.) in Norway. J Appl Ecol 28: $102-108$.

Andreska J (1988) Počátky a vývoj populace losa (Alces alces L., 1758) v jižních Čechách. Lynx 24: 73-77.

Ball JP, Nordengren C, Wallin K (2001) Partial migration by large ungulates: characteristics of seasonal moose Alces alces ranges in northern Sweden. Wildlife Biol 7: 39-47.

Bauer K, Nygrén K (1999) Alces alces (Linnaeus, 1758). In: Mitchell-Jones AJ, Amori G, Bogdanowicz W, Kryštufek B, Reijnders PJH, Spitzenberger F, Stubbe M, Thissen JBM, Vohralík V, Zima J (eds) The Atlas of European Mammals. Academic Press, London, pp 394-395.

Borkowski J (2004) Distribution and habitat use by red and roe deer following a large forest fire in South-western Poland. Forest Ecol Manag 201: 287-293.

Čejka J (2001) Vliv přítomnosti rysa ostrovida (Lynx lynx) na etoekologii jelena evropského (Cervus elaphus) a srnce obecného (Capreolus capreolus) v podmínkách Šumavy. MSc. Thesis. Dpt. of Zoology, Biological Faculty, South Bohemian University České Budějovice.

Čejka J (1998) Zjištění populační hustoty srnce obecného (Capreolus capreolus) a jelena evropského (Cervus elaphus) v horské oblasti Šumavy. Bc. Thesis. Dpt. of Zoology, Biological Faculty, South Bohemian University České Budějovice.

Clutton-Brock TH, Guinness FE, Albon SD (1982) Red deer: behavior and ecology of two sexes. University of Chicago Press, Chicago.

Corbet GB (1978) The Mammals of the Palearctic Region: a taxonomic review. British Museum (Natural History), London. 
Courtois R, Dussault Ch, Potvin F, Daigle G (2002) Habitat Selection by Moose (Alces alces) in Clear-Cut Landscapes. Alces 38: 177-192.

Frair JL, Merrill EH, Beyer HL, Morales JM (2008) Thresholds in landscape connectivity and mortality risks in response to growing road networks. J Appl Ecol 45: 1504-1513.

Gillingham MP, Parker KL (2008) Differential habitat selection by moose and elk in the Besa-Prophet area of nothern British Columbia. Alces 44: 41-63.

Godvik IMR, Loe LE, Vik JO, Veiberg V, Langvatn R, Mysterud A (2009) Temporal scales, trade-offs, and functional responses in red deer habitat selection. Ecology 90: 699-710.

Grubb P (2005) Order Artiodactyla. In: Wilson DE, Reeder DM (eds) Mammal species of the world. Vol. 1. 3rd edition. The Johns Hopkins University Press, Baltimore, pp 637-722.

Hlaváč V, Anděl P (2001) Metodická př́ručka k zajištování průchodnosti komunikací pro volně žijící živočichy. AOPK ČR, Praha.

Homolka M (1998) Moose (Alces alces) in the Czech Republic: Chances for survival in the man made landscape. Folia Zool 1: 1-46.

Homolka M (2000) Los evropský (Alces alces) v ČR a jeho šance na přežití v kulturní krajině. Ochrana př́rody 55: 195-199.

Homolka M, Heroldová M (1997) Vliv losa evropského (Alces alces) na lesní porosty, stanovení populační hustoty a management populace v České republice. Unpublished manuscript of ÚEK AV ČR.

Hutr K (2004) Los evropský v našich honitbách. Svět myslivosti 5: 23-25.

Jones PF, Hudson RJ (2002) Winter Habitat Selection at Three Spatial Scales by American elk, Cervus elaphus, in West-Central Alberta. Can Field Nat 116: 183-191.

Kamler J (2010) Strašák jménem „Hodnocení vlivu zvěře na ekosystém“ aneb Jaké změny v plánování lovu nám hrozí? Myslivost 3: $12-15$

Kamler J, Plhal R (2010) Hospodaření s únosnými stavy zvěře. Myslivost 4: 22-23.

Koubek P, Zima J (1999) Cervus elaphus Linnaeus, 1758. In: Mitchell-Jones AJ, Amori G, Bogdanowicz W, Kryštufek B, Reijnders PJH, Spitzenberger F, Stubbe M, Thissen JBM, Vohralík V, Zima J (eds) The Atlas of European Mammals. Academic Press, London, pp. 388-389.

Kuchyňka V (1994) Ještě jednou losi. Myslivec 12: 1-2.

Kyselý R (2005) Archeologické doklady divokých savců na území ČR v období neolitu po novověk. Lynx 36: 55-101.

Lepš J, Šmilauer P (2007) Multivariate Analysis of Ecological Data Using CANOCO. 3rd edition. Cambridge University Press, Cambridge.

MacCracken JG, Van Ballenberghe V, Peek JM (1997) Habitat Relationships of Moose on the Copper River Delta in Coastal South-Central Alaska. Wildlife Monogr 136: 3-52.

Marada P (2010) Chrání myslivci prŕrodu a krajinu? Myslivost 4: $16-17$.
Märtl J (2009) Los evropský na Vyšebrodsku. Svět myslivosti 10: 10

McLoughlin PD, Coulson T, Clutton-Brock T (2008) Cross-generational effects of habitat and density on life history in red deer. Ecology 89: 3317-3326.

Mrlík V (1996) Los evropský v ČR dříve a nyní. Živa 1: 42-43.

Mrlík V (1998) Los - Alces alces v hraniční oblasti jihovýchodních Čech a přilehlé části Rakouska. Myslivost 3: 14-15.

Mysterud A (1999) Seasonal migration pattern and home range of roe deer in an altitudinal gradient in southern Norway. J Zool 247: 497-486.

Mysterud A, Langvanth R, Yoccoz NG, Stenseth NC (2002) Largescale habitat variability, delayed density effects and red deer populations in Norway. J Anim Ecol 71: 569-580.

Nikula A, Heikkinen S, Helle E (2004) Habitat selection of adult moose Alces alces at two spatial scales in central Finland. Wildlife Biol 10: 121-135.

Peške L (1995) Archaeozoological records of elk (Alces alces) in the Czech Republic. Acta Soc Zool Bohem 59: 109-114.

Pfeifer K (2010) Myslivecká statistika jen potvrzuje problémy v mysliveckém plánování. Myslivost 3: 58-59.

Prokešová J, Barančeková M, Homolka M (2006) Density of red and roe deer and their distribution in relation to different habitat characteristics in a floodplain forest. Folia Zool 55: 1-14.

Raczyński J (2008) Die Zukunft des Elches (Alces alces) in Polen zwischen Jagd und Schutz. Säugetierkundliche Informationen Jena 6: 151-160.

Rolandsen CM, Solberg EJ, Bjøerneraas K, Heim M, Van Moorter B, Herfindal I, Garel M, Pedersen PH, Sæther BE, Lykkja ON, Os $\varnothing$ (2010) Moose in Nord-Trøndelag, Bindal and Rissa 20052010 - Final report. Rapport no. 588. The Norwegian Institute for Nature Research, NINA, Trondheim.

Romportl D, Chuman T, Lipský Z (2010) Landscape heterogenity changes and their driving forces in the Czech Republic after 1990. In: Bičík I, Himiyama Y, Feranec J (eds) Land Use/ Cover Changes in Selected Regions in the World. IGU-LUCC Research Report, Volume V, Charles University, Faculty of Science, Prague, pp 41-50.

Ševč́́k J (1994) Los a jeho cesta do Evropy. Myslivec 10: 3.

Ševčík J (1995) Losi do třetice. Myslivec 2: 4.

StatSoft (2001) Statistica for Windows [Computer program manual]. StatSoft, Inc., 2300 East 14th Street, Tulsa, USA.

Suchánková V (2009) U Hodkovic byl sražený los. Policie České republiky - KǨP Ústeckého kraje. www.policie.cz/clanek/u -hodkovic-byl-srazeny-los.aspx, accessed at: 2011.09.14

Šustr P (2010) Losovi na stopě. Šumava 15: 18-19.

Šustr P (2007) Kudy chodí šumavští jeleni? Šumava 12: 20-21.

Ter Braak CFJ, Šmilauer P (2002) CANOCO Reference Manual and CanoDraw for Windows User's Guide: Software for Canonical Community Ordination (version 4.5). Microcomputer Power, Ithaca, NY.

Welch D, Staines BW, Catt DC, Scott D (1990) Habitat use by red (Cervus elaphus) and roe (Capreolus capreolus) deer in a Scottisch sitka spruse plantation. J Zool 221: 453-476. 